\title{
REFLEKSJA ZARÓWNO SOCJOLOGICZNA, JAK \\ I TEOLOGICZNA: \\ ROZMOWA Z KIERANEM \\ FLANAGANEM
}

\section{/// Wprowadzenie}

„Zarówno socjologia, jak i teologia zainteresowane są kondycją ludzką, ale mają różne ramy odniesienia. Obie dziedziny przynależą do różnych uniwersów dyskursu. Pytania, jakie stawia się w kategoriach tego pierwszego [dyskursu], nie mogą znaleźć odpowiedzi w kategoriach tego drugiego" (Mills 1980: 1-2, tłum. KM). Tak John Orme Mills rozpoczął pewien zbiór esejów, którego celem było nawiązanie dialogu między tymi dwiema dyscyplinami. Patrząc wstecz, wydaje się, że ta propozycja nie padła na podatny grunt. Z jednej strony, John Milbank opublikował w 1990 roku swa pracę pt. Theology and Social Theory, próbując zakwestionować ważność [validity] socjologii na tej podstawie, że świecki charakter jej obszaru zainteresowania - będący podstawowym założeniem dyscypliny - jest w znacznej mierze produktem teologii. Z drugiej zaś strony, socjologowie prowadzili swoje badania niemal bez teologicznego podszeptu.

Jest to osobliwy stan rzeczy. Jakkolwiek by było, refleksje teologiczne z konieczności wkraczają na terytorium świata społecznego. Pytania teologiczne są stawiane przez formy religijne i te formy bez wattpienia przynależa do świata ziemskiego (w tym miejscu nie ma potrzeby wchodzić w głębsze rozważania na ten temat, nie jest konieczne rozpatrywanie związku między religia a sferą transcendentalną, którą ta pierwsza postuluje). Jeśli teologia chce zejść na ziemię, to powinna/musi otworzyć się na zagadnienia socjologiczne. Zatem socjologia także musi skonfrontować się z tymi teologicznymi wyzwaniami: „skoro współcześnie przyjmuje się, że religia posiada 
pewne istotne aspekty, a wiara ulega kontekstualizacji, teologiczna podstawa religii wymaga przemyślenia" (Flanagan 2001a: 2). Podobnie pewna siebie socjologiczna narracja o sekularyzacji zostaje podana w watpliwość ze względu na wzrost społecznego znaczenia kwestii religijnych. Fenomen wojującego ateizmu pokazuje aktualność problemów teologicznych i ich niedostępność dla świeckich umysłów.

Odrzucenie dialogu przez te dwa odmienne dyskursy jest interesujące także z innego powodu. Zarówno teologia, jak i socjologia promuja refleksyjność w ramach tego, co teologiczne lub socjologiczne. Z tego wynika, że socjologowie wyczuleni na teologię, zachowując otwartość umysłu, będą doświadczali złożonej refleksyjności. Pewność uzyskiwana w jednej dziedzinie będzie rodziła niepokój dla praktyk tej drugiej. Dylemat może zostać rozwiązany tylko przez akt wiary zarówno po jednej, jak i po drugiej stronie. Możliwa jest jednak dalsza dualna refleksyjność, po to by sprawdzić, dokąa może ona doprowadzić i jak może się przyczynić do wzajemnego wzbogacenia.

Takie jest stanowisko - zarówno teologiczne, jak i socjologiczne - jakie przyjmuje w swych pracach Kieran Flanagan. Pracujący na Wydziale Socjologii Uniwersytetu w Bristolu Flanagan jest autorem serii prowokujących prac osadzonych zarówno $w$ socjologii, jak i $w$ teologii, ale sytuujących się poza dogmatami każdej z nich (Flanagan 1991, 1996, 2004, 2007). Dla jego prac charakterystyczne jest spostrzeżenie, że i teologiczne, i socjologiczne ramy odniesienia moga być istotnym przyczynkiem do rozumienia współczesnej kondycji ludzkiej. I być może właśnie ze względu na to, że wymagaja znajomości obu tych dyscyplin, prace Flanagana nie zyskały jeszcze zasłużonego zainteresowania ze strony czytelników.

Ten artykuł stanowi pierwszą próbę udostępnienia prac Flanagana szerszej publiczności. Jest to rozmowa, w której Flanagan odpowiada na pytania zadawane w celu ukazania motywów, założeń i stawek tego projektu. Ryzykując pomieszanie metafor, mam nadzieję, że ta rozmowa okaże się przydatna jako przewodnik po gęstej sieci dróg i bocznych ścieżek przez prace Flanagana, a także jako zaproszenie do pobudzenia refleksyjności teologicznej w socjologii oraz refleksyjności socjologicznej w teologii. Jasne jest, że Flanagan pracuje w ramach jednej tradycji teologicznej, mianowicie katolickiej, lecz choć sam podzielam tę afiliację, to artykuł nie był pisany w celu nawracania czy ewangelizacji. Rozmowa ta jest sposobem wejścia w tematykę tych prac i zaproszeniem do dalszej refleksji, refleksji, której prawdopodobnym elementem jest krytyka prac Flanagana, jeśli nie wręcz ukazanie radykalnie odmiennych kategorii teologicznych. 


\section{/// Rozmowa}

Keith Tester: Kiedyś napisateś, że socjologowie sa ,gatunkiem matomównym” (Flanagan 1986: 256), szcrególnie gdy chodzৃi o deklaracje wiary religijnej. Socjologowie maja sketonność do milczenia na temat swojego religijnego zaangażowania, a katolicy, potegujac jeszcze te niewidzialność, maja sktonność do nieokazywania przesadnego enturjazmu wobec otwartego identyfikowania sie w keregach akademickich jako praktykujacy keatolicy. Ale Ty nie masz problemu, by identyfikować sie jako socjolog i jako katolik. $Z$ czego bierže sie ta pewność siebie i dlaczego te identyfikacje sq dla Ciebie wažne?

Kieran Flanagan: Pewność siebie związana z byciem katolikiem wzięła się z mojego doświadczenia konwersji w Downside Abbey w Anglii w 1976 roku (Flanagan 2009a). Jej rezultatem było wzmocnienie religijnej refleksyjności w postaci teologicznej, która przenika moje rozważania socjologiczne. Katolicyzm jest podpora mojego powołania do bycia socjologiem. Dał mi stabilność, tożsamość i spokój ducha w zmaganiu się z obrzeżami socjologii, gdzie praca analityczna jest wysoce niestabilna.

Choć urodziłem się i wychowałem jako katolik, w czasach studenckich opowiedziałem się po stronie wojującego ateizmu. Katolicyzm nie był nawet w zasięgu mojego socjologicznego radaru. Ku mojemu zdziwieniu moja wrażliwość religijna została wskrzeszona dzięki śpiewom chóru podczas zwyczajnej wizyty na wieczornej mszy w katedrze anglikańskiej w Bristolu w 1975 roku. Podziałało to na moją wyobraźnię duchową i socjologiczną. Ten rytuał był zadziwiająco bezsensowny, a mimo to odgrywany z grobową powaga i rozmachem. Zamiast pustego korowodu odtwarzanego z nudy w mauzoleum wiary, rozwijał się tajemniczo, sięgając do tego, co nadprzyrodzone, i otrzymując w zamian echa tego, co boskie. Zobaczywszy wersje anglikańska, przemieściłem się do innej katedry w Bristolu, w Clifton. W tym nowym miejscu pewnie nawet w większym stopniu, niż sam chciałbym przyznać, mój katolicyzm zapuścił korzenie i nabrał kształtu. To doświadczenie pozwoliło mi znaleźć zasoby mądrości i przekonujące doktryny. Zasoby katolicyzmu nie były przedmiotami wystawionymi do oglądania, ale były do użytku dla wszystkich, tych wielkich i dobrych, tych słabych i małych, wesołków i sztywniaków, wielkich umysłów teologicznych, a nawet tych cierpiących z powodu swoich małych socjologicznych móżdżków. Dziwny to klub, w którym nikt nie jest wykluczany, a który zaprasza wszystkich.

Geniusz katolicyzmu leży w jego mądrości, zakumulowanej przez wieki, w obchodzeniu się z wyżynami cnoty i czeluściami występku za pomoca zasobów współczucia niemających sobie równych w żadnym innym systemie wiary. $\mathrm{W}$ przeciwieństwie do wizerunku prezentowanego $\mathrm{w}$ mediach 
katolicyzm jest genialny w swoim współczuciu i człowieczeństwie. Gdy zestawić w jednym szeregu Muriel Spark ${ }^{1}$ i Maxa Webera, dlaczego nie podróżować pierwszą klasa, by kupić zbawienie?

Gdybym wskazał, że moja socjologia była ukształtowana przez judaizm lub islam, z dużym prawdopodobieństwem inni socjologowie zareagowaliby życzliwie. Określenie się jako katolik w polu socjologicznym prowadzi do kreatywnego stanu liminalnego, ale także niesie ryzyko, że to, co będzie produkowane, trafi w próżnię, bo socjologowie nie mają wystarczającej wiedzy teologicznej, by zrozumieć, o co chodzi, i vice versa.

KT: Ciagle podkreślateś, że pozostajesz dlużny Hansowi Ursowi van Balthasarowi (por. np. Flanagan 1986, 1996), i chciatbym Cie zapytać o ten wptyw. Autor ten napisat, ie Cztowiek ,żyje jako ograniczona istota w ograniczonym świecie, ale jego umyst jest otwarty na to, co nieograniczone, na cate istnienie" (Balthasar 1991, ttum. KM). Z tego zaś Balthasar wywiódt potrzebe teoestetyki (jak sie objawia Bóg jako nieskończoność? Czyli pytanie o piekno), teo-dramy (w jaki sposób Bóg nawiazuje relacje z ograniczonym Cztowiekiem? Cayli kwestia dobra) oraz teologii (w jaki sposób nieskonczony Bóg może dać sie poznać ograniczonemu człowiekowi? Cayli kwestia prawdy). To jest bardzo podstawowa klasyfikacja z bogatej twórczości Balthasara $i$ chciatbym zasugerować, że na niej opiera sie Twoja ,trylogia”. W Enchantment of Sociology (1996), Seen and Unseen (2004) oraz Sociology in Theology (2007) znajdijemy Twoje odpowied zi na wezwanie do teoestetyki i teodramy. $C_{z y}$ odniesienie tych prac do koncepcji Balthasara jest uprawnione? A przede wsyystkim, dlaczego Balthasar?

KF: Moje pierwsze wysiłki w polu socjologii religii, by przemieszczać się ku teologii, rozpoczęły się od dwóch esejów o społecznej konstrukcji liturgii (1981a) i niewinności (1981b). Jak na ironię, traktat o liturgii powstał w stanie błogiej teologicznej niewiedzy. Te dwa eseje ukształtowały to, co miało nastapić w Sociology and Liturgy (1991). Badanie poświęcone liturgii w 1980 roku dotyczyło bardzo prostego zagadnienia, mianowicie tego, jak dwa idealne typy rytuału, prosty i złożony, mogły współistnieć w tej samej wspólnocie. To tak, jak gdyby w formie liturgicznej społeczne zasoby rytuału były wyjęte spod regulacji, kształtowania i podtrzymywania granic. Uznając, że liturgie związane są z tym, co nieograniczone, z pewnością nie można argumentować, że także ich formy są podobnie trwale nieograniczone i nieskończenie plastyczne. Czy podtrzymywanie granic liturgicznych było kwestią teologiczną czy czysto socjologiczną, czy jednym i drugim?

\footnotetext{
${ }^{1}$ Muriel Spark - szkocka powieściopisarka (1918-2006). Na język polski przetłumaczono m.in. Petnie życia panny Brodie (wyd. angielskie 1961). Urodziła się w rodzinie żyda i prezbiterianki, została wychowana w wierze swojej matki. W latach pięćdziesiątych przeszła na katolicyzm. Twierdziła, że dopiero to dało jej możliwość całościowego postrzegania ludzkiego doświadczenia (por. Hager 1999: 141, przyp. tłum.).
} 
W odpowiedzi na to pytanie antynomia granic i tego, co bezgraniczne, została opisana w kategoriach hermeneutycznych, początkowo w dwóch esejach z lat 1986 i 1988, dopracowanych następnie w Sociology and Liturgy (1991). Sfera społeczna została potraktowana tak, jak gdyby była tekstem, z obiektywnymi ograniczeniami, którego pełne zrozumienie wymagało odniesienia do nieograniczonych horyzontów, otwartych poprzez akt ich ustanowienia. Tym samym praktykę rytuałów scharakteryzowano jako próbę wyjścia poza ramy społeczne. To wyjście zaś potraktowano w kategoriach numinosum i ciszy, zjawisk charakterystycznych dla teologii apofatycznej. Do tej specjalizacji teologicznej dotarłem przez przypadek i z powodu swej niewiedzy. Nie mając żadnego przewodnika w tej dziedzinie, nie potrafiłem znaleźć punktu wyjścia do rozwiania moich wątpliwości socjologicznych. Rahner był dziwnie niepodatny na badania socjologiczne, teologia wyzwolenia zwulgaryzowała Marksa i wydawała się niewrażliwa na kwestie podejmowane przez Webera, a dokumenty z Soboru Watykańskiego II odnoszące się do kultury i nowoczesności zdawały się nie zważać na swe implikacje socjologiczne. W 1984 roku zacząłem czytać pierwszy tom Chwaty Pana [The Glory of the Lord] Balthasara (1982). To było niczym objawienie, dobra kanwa do socjologicznych rysunków i wzorów w teologicznych ramach. Odkryłem mojego teologa. Trzeci tom Chwaly Pana był dla mnie szczególnie pomocny, gdyż zawierał uznanie dla uprawiania teologii przez świeckich (Balthasar 1986, 1996). Autor był nieoceniony także $z$ wielu innych powodów. Jego prace dostarczały wiedzy teologicznej z odniesieniami do Augustyna, Bonifacego, Orygenesa i innych. Ale, co najważniejsze, otworzyły przede mną myśl Pseudo-Dionizego Areopagity, którego pojęcia wznoszących się i opadających kręgów oraz jego symbolizm i zagadnienie aniołów dały mi ramę teologiczną i wizję do Sociology and Liturgy. W tej pierwszej książce wpływ Balthasara był najmocniej wyczuwalny. Jego prace ukształtowały także The Enchantment of Sociology (1996), ale w późniejszych rozważaniach na temat kultury wizualnej schodza na dalszy plan. Zainteresowanie Balthasara estetyka dotyczyło muzyki, literatury i filozofii. Mimo jego afirmacji dla wymiarów teologicznych estetyki w jego twórczości jest osobliwie mało odniesień do wizualności, do konkretnych wizerunków zakorzenionych w kulturze.

Balthasar niewiele pisał wprost o socjologii, ale gdy już pojawiało się takie odniesienie, było znamiennie dobrze przebadane. Jego refleksje o socjologii można odnaleźć w krótkim fragmencie pracy pt. Theo-Drama, w którym stawia pytanie: „kim jestem?” (Balthasar 1988: 531-544). Ten wycinek zawiera krótkie odniesienie do Simmela i jego zainteresowania rolami społecznymi, tragedią i grą, a także niespodziewane uznanie dla 
Cźtowieka w teatrze sycia codziennego (wyd. pol. 1977), którą to koncepcję wykorzystuje do przedstawienia swojego poglądu na „teatr świata” (Balthasar 1988: 481; 541 i n. 57). Lańcuch, który łączy [te odniesienia], jest frustrująco krótki. Zważywszy, że Balthasar był niczym wydział sztuk pięknych zamknięty w jednym umyśle, być może odnalezienie odniesień do Simmela i Goffmana w tak odmiennym kontekście jest czymś, za co powinniśmy być wdzięczni. Tak oto socjologia dotarła na obrzeża jego teologii estetyki.

W niezręczny sposób usiłowałem przesunąc refleksję socjologiczną poza tę granicę. W pracach Balthasara znalazłem zezwolenie na bycie socjologiem w teologii. W latach osiemdziesiątych XX wieku znalazłem pocieszenie także w pismach kardynała Josepha Ratzingera (późniejszego papieża Benedykta XVI) na temat liturgii, mimo iż były one krytykowane przez angielskich liberalnych katolików. Nikt nie mógł na poważnie traktować ich jako nieudanych socjologów, a każdy z nich zaopatrzył mnie w broń do walki na polu teologii bez zbytniego ryzyka poniesienia obrażeń duchowych.

KT: Zgodnie ₹ Katechizmem Kościoła Katolickiego „nale ̇̇y starannie odróżniać postęp ziemski od warostu Królestwa Chrystusowego” ${ }^{2}$. Ten fragment wyjaśnia, że jedno nie rośnie w site w parze z tym drugim tak, $i \dot{z}$ Królestwo Boże staje sie stopniowo coraz. blizsze w miare spotecznego i kulturowego „postepu”, a takize jest praypomnieniem, by zajać sie cazymś wiecej niż tylko ograniczonymi darami, jakie oferowane sq tu i teraz. Katechizm mówi jednak takize, że rozróżnienie między Królestwem Bozym a społeczno-kulturonym polożeniem ludzi ,nie jest rozdzieleniem” (Katechizm, kan. 2820). Innymi stowy, Królestwo Boże oraz to, co kulturowe i spoteczne, maja zwiazek analogiczny; ślady tego pierwszego można dostrzec w tym ostatnim, ponieważ sq one podobne, choć ró:żne. Ta myśl odsyla nas zpowrotem do rozróżnienia między skończonym i nieskończonym, które sformutowat Balthasar. Cay to thumaczy Twoje socjologiczne zainteresowanie modlitwa $i$ Eucharystia (Flanagan 1991)? Caym musi zajmować sie każda socjologia modlitwy i praktyk liturgicznych?

KF: To jest fascynujące pytanie. Słusznie zwracasz uwagę na analogiczny związek między Królestwem Bożym a kulturą i społeczeństwem jako sfer podobnych, choć różnych. To właśnie owo rozczłonkowanie tego

\footnotetext{
${ }^{2}$ Pełne brzmienie kanonu 1049 KKK to: „Oczekiwanie jednak nowej ziemi nie powinno osłabiać, lecz ma raczej pobudzać zapobiegliwość, aby uprawiać tę ziemię, na której wzrasta ciało nowej rodziny ludzkiej, mogace dać pewne wyobrażenie nowego świata. Przeto, choć należy starannie odróżniać postęp ziemski od wzrostu Królestwa Chrystusowego, to przecież dla Królestwa Bożego nie jest obojętne, jak dalece postęp ten może przyczynić się do lepszego urządzenia społeczności ludzkiej” - przyp. tłum.
} 
analogicznego związku leży u podstaw moich socjologicznych obaw związanych z kierunkiem, jaki obrały współczesne teologiczne interpretacje kultury. Wiele czerpię tu od Benedykta XVI, który w odniesieniu do socjologii wykazał się dużo większą ostrożnością niż wszyscy jego poprzednicy. Jego pojęcie hermeneutyki ciagłości ilustruje ten argument. Ten nacisk na rehabilitację tradycji zawiera istotny moment kulturowy.

Hermeneutyka ciagłości sugeruje potrzebę pewnej formy odzyskania [tego, co utracone - przyp. tłum]. Ten imperatyw znajduje wyraz w niedawnym studium poszukiwań duchowych młodych Kalifornijczyków (Flory i Miller 2008: 124-56). W tej pracy wykorzystywany jest termin „odzyskujący” [reclaimers] w odniesieniu do tych młodych wiernych, którzy uznają tradycyjne formy religijności anglikańskiej i katolickiej za środki do nawiązywania szerszych więzi teologicznych. W formalnych liturgiach przywiązanie jest tak kształtowane, by jeszcze bardziej uwrażliwić na sacrum, nierzadko odczuwane namacalnie przez kadzidła, szaty i bogactwo zasobów symbolicznych. Dalecy od bycia bezmyślnymi konserwatystami, ci młodzi „odzyskujący” są innowatorami dążącymi do przekształcenia religijnych tradycji tak, by uciec od braku znaczenia, jaki cechuje kulturę, którą odziedziczyli. Zwracają się oni przeciwko zadziwiającemu uprzedzeniu liberałów, którzy traktują tradycję jako coś nudnego. Ci „odzyskani” nie są konserwatystami albo liberałami, są nowymi radykałami swoich czasów, którzy rehabilitują to, co zostało odrzucone, i przywracają do życia to, co wydawało się martwe.

Analiza granic i ich analogicznego związku z bezgranicznością znajduje najpełniejszy wyraz w Sociology and Liturgy. Związek między granicami a bezgranicznością w rytuale religijnym jest głęboko dwuznaczny i zrozumienie zachowania tej nieokreśloności podczas odbywania rytuału było podstawowym problemem rozważanym w tym pierwszym studium. Poprzez skupienie się na potknięciach związanych z czynnościami liturgicznymi wattpliwości związane $z$ radzeniem sobie $z$ tymi antynomiami i dwuznacznościami wypłynęły na pierwszy plan. Choć nacisk położony na te kwestie mógł skazać te rytuały na niekończące się i bezpłodne spory, wykorzystanie teologii negatywnej, wyrażanej zwłaszcza w kategorii ciszy, pozostawiało otwartą możliwość transcendencji i odkupienia. Te perspektywy wzbudziły wśród aktorów potrzebę odróżnienia między korzystnymi dwuznacznościami, cechującymi się odniesieniem do numinosum, a bezużytecznymi dwuznacznościami performansu, które sprawiały, że rytuały działały dosłownie i były nieskuteczne w sensie podtrzymywania otwarcia na to, co święte. To, co dosłowne w rytuałach, jest zawsze zbywalne, ponieważ zmusza aktorów liturgicznych do koncentracji na naprawie, a nie na perspektywie uniesienia. 
Związek zachodzący między kategoriami granic i nieskończoności nie jest wyłącznie antynomiczny. Mają tajemnicze właściwości wzajemnego zastępowania się, co przedstawia zagadkę ich analogicznych związków. W dążeniu do kapłańskiej czystości odgrywania aktorzy liturgiczni czasem nieoczekiwanie urzeczywistniają zespolenie granic (formy społecznej) z tym, co bezgraniczne (treść teologiczna) w epifaniach, momentach prawdziwego ziszczenia. W tym studium to, co graniczne, było miejscem tymczasowym między granicami a tym, co bezgraniczne. Ministrant nie tylko zajmował pozycję graniczną - on uosabiał właściwości graniczności. W tej roli niewinnie nabierał nadzwyczajnych mocy.

Zainteresowanie niewinnościa, jakie znalazło swój wyraz w tym studium, odzwierciedlało życzeniowe myślenie o socjologii jako takiej. Czaiło się w nich uświadomienie sobie, że była ona dyscypliną upadłą, a także poczucie konieczności dojrzałych doświadczeń, poczucie, że jest to dyscyplina, która nie przeszła testu pojmowania granic swojego samozrozumienia. Te zagadnienia znalazły się na pierwszym planie w studium liturgii, gdzie socjologia dusiła się w swych niekończących się wątpliwościach. Strach przed analitycznym owładnięciem popchnął socjologię ku poszukiwaniu możliwości zbawienia, takich, w których niewinność mogła przekroczyć to, co wynurzało się z doświadczenia.

The Enchantment of Sociology przyłapała socjologie na polu kultury. Pisanie tej pracy odzwierciedlało mój wysiłek, by uciec od Sociology and Liturgy. Napisane w latach 1992-1995 The Enchantment było dziwacznie inkluzywnym studium, w którym zmagałem się najpierw z Simmelem i Bourdieu oraz próbowałem zmusić socjologię do rozważań refleksyjnych, szczególnie takich, które wypływały z koncepcji habitusu. Nic dziwnego, że olśniła mnie kwestia następująca - jeśli refleksyjność była wynikiem pracy w terenie, to cóż socjologia miała tam zobaczyć? To zaś prowadziło mnie do uświadomienia sobie, że kluczowym wymiarem refleksyjności była wizualność, zwłaszcza w związku ze wzrostem znaczenia kultury cyfrowej i wizualnej. Poszukiwanie odpowiedzi na pytanie o to, co właściwie dzieje się w tej sferze, doprowadziło do powstania co najmniej dwóch książek (Flanagan 2004; 2007). Te prace dodały do pojęcia granic i bezgraniczności wymiar wizualny przez odniesienie do tego, co jest widziane i niewidziane, tego, co jest ograniczone do oka zmysłowego, a co jest ćwiczeniem dla oka duchowego.

Gdy teraz powracam do tych prac, frapujące wydają mi się wyłaniające się z nich wspólne wątki: niebezpieczeństwa ciekawości, konieczność dwuznaczności, antynomie (niewinność i doświadczenie, widzialne i niewidzialne) oraz tarapaty samej socjologii, jeśli chodzi o to, do czego chce zmierzać, 
i to, co przetwarza [refracts] jako dyscyplina akademicka. Prace socjologów trapią zniekształcenia i chęć odkupienia. Wciąż wyłania się wszechobecność tego, co społeczne, oraz paranoja socjologii, wyrażana przez strach zanurzenia się w tym. Te dylematy uobecniają się w pojęciu ślepowidzenia. Jest to cecha sekularności, gdzie socjologii odmawia się zdolności do nazywania tego, co widzi ${ }^{3}$.

Obecnie pisze Sociology at Prayer: Utterances in the Wilderness. W tej pracy powracam do problemu z pierwszego studium, mianowicie znajdowania tego, co społeczne, ale na sposoby, które akcentuja jego transformacyjna podstawę przez mimesis. Gdyby modlitwa dotyczyła tylko tego, co społeczne, jak twierdził Marcel Mauss, zdawałaby się bezcelowa formą prośby. Modlitwa wciąga modlących się w sferę bezgraniczności w tajemny sposób, przekraczający granice narzucone przez to, co społeczne, ale bez aroganckiego lekceważenia potrzeby pielęgnowania jego wszechobecności. Przez odniesienie do transcendencji i do Wcielenia teologia ukazuje badaczom zagadkową dwubiegunowość. Pogodzenie obu biegunów wykracza poza ludzkie możliwości. Granice i bezgraniczność są socjologiczną wersją tajemniczej antynomii Wcielenia i transcendencji, która leży w sercu rozważań teologicznych.

KT: Skoro spoteczeństwo i kultura sq analogiczne do tego, co nieskończone, to w jaki sposób socjologia może wyjaśniać dorozumiany wymiar niesekularny? Zgodnie z tym, co mówi John Milbank, socjologia jest dyscyplina zamknieta w swieckiej formie rozumienia - a zarazem taka tylko forme rozumienia uytwarza (Milbank 1990). Można powiedzieć, że socjologia jest ograniczona i ograniczajaca. Sam pisateś, że dzieki rozumieniu socjologicznemu, ,uygodne rozwiazania społeczne zapewniajace dostarczanie wartości i ideałów staja sie przedmiotem krytycznego ogladu, który wttacza to, co duchowe i estetyczne, w ramy analityczne... to, co znaczqce, przedstawia sie jako kruche" (Flanagan 1986: 258). Teologiczna sketonnościq w socjologii zdaja sie niewiara lub ktopotliwe milcrenie. Dlaczego jesteś tak zatroskany stanem socjologii? I caym jest dla Ciebie socjologia?

KF: Wiara religijna rzadko kiedy bywa zabezpieczona dzięki pożądanym warunkom; gdyby było inaczej, zamieszkiwalibyśmy w fantastycznych krainach urządzonych tak, by lepiej zabezpieczyć nasz poziom moralny. Wiara musi znaleźć umocowanie w niepomyślnych warunkach, często takich, których sobie nie wybieramy. Być może to jest świadectwo, które socjologia składa teologii.

\footnotetext{
${ }^{3}$ „Termin ślepowidzenie odnosi się do zdolności widzenia, lecz niezdolności nazwania tego, co jest widziane. Porażka rozróżnienia powoduje wszelkiego rodzaju pułapki, szczególnie w kulturze, w której wizualność stała się dominującą formą ekspresji” (Flanagan 2009b: 18).
} 
Nadejście nowoczesności wymagało wynalezienia socjologii. Była to dyscyplina, która umożliwiła nowoczesności opisanie samej siebie w nowym świecie, w którym tak rozwinięte były kalkulacja, spektakl i wymiana. Te trzy zjawiska wzmogły uświadomienie sobie tego, co społeczne, zwłaszcza ludziom wykorzenionym i prowadzącym niespokojne życie w mieście. Socjologia została wymyślona, by scharakteryzować ten wykładniczy przyrost życia społecznego w sztucznym tyglu miasta. Ale to watpliwa delegacja, jako że socjologia wie, że reifikuje byty oraz że im bardziej je reifikuje, tym bardziej w wyniku działania obiektywnych sił kurczy się sfera subiektywna. To był dylemat, który przedstawił Simmel w swoim pojęciu tragedii kultury.

Simmel wyraził nieciągłość między nieuchwytną subiektywną treścią życia codziennego (co odnosi się do estetyki lub tego, co duchowe) a obiektywizującymi formami używanymi do porządkowania i manifestowania ich odrębności. Tragedia polega na tym, że formy zaczynaja żyć własnym życiem, podważając treści, które miały oswajać. Tak więc przeznaczeniem socjologii jest nieskończona mnogość analiz wielości form społecznych, ale bez widoków na przekroczenie owych form przy użyciu własnych zasobów. Simmel sięgnął po dzieła Mikołaja z Kuzy w odniesieniu do zdolności Boga do przekraczania wszystkich przeciwności (Simmel 1997)i iw ten sposób położył fundamenty pod negatywną teologię w socjologii. Wspominając o tym, nie mam zamiaru narażać socjologii na imperialistyczne roszczenia teologii wysuwane przez Milbanka. To, czego on dostarcza, to karykatura socjologii, bezbożna i niezdolna do współudziału w Mieście Boga. Ale to miasto na Ziemi ma wiele labiryntów, które wymagaja zbadania przez socjologa, nawet jeśli tylko po to, by dostarczyć mapy, na której można by umieścić spostrzeżenia odsyłające do teologii. Wiele, wiele obszarów w socjologii jest bardzo odległych od teologii. Kwestie teologiczne pojawiają się jednak w zagadnieniach takich, jak: jaźń [self], tożsamość, charakterystyka kultury, płeć kulturowa, seksualność, cielesność i śmierć.

KT: Chciatbym, żebysmy poszli dalej $i$ zajeli się kultura troche bardziej sz̨çegótowo. W kategoriach teologicznych kulture możemy opisać jako te sfere, przez która i w k.tórej pojawia sie to, co bezgraniczne, ketóra jest swojego rodzaju dźwignia dzieki której ograniczony Cztowiek moze nyjrzeć poza swe ograniczenia i spojrzéc w kierunku tego, co bezgraniczne. W ujeciu Balthasara kultura jest sfera, w której to, co bezkeresne, spotyka sie w sposób konkretny. Czy to oznacza, że w efekcie kultura jest przestrzenia przez ketóra chwata wdziera sie do tego swiata? A jeśli tak, to çy możesz wyttumaczýc, co to doktadnie oznacza? 
KF: Kultura to gleba dla wiary, miejsce jej manifestacji i zasoby służące do jej przekraczania i sięgania w sfery bezkresne. Z samej swej natury kultura zajmuje się sprawami wznoszenia się, zaczarowania i transfiguracji, jak u Arnolda, Webera i Durkheima. Analizując te nienamacalne właściwości, socjologia musi się zmierzyć $z$ wyborem: albo traktować je jako fenomeny pochodzące ze sfery społecznej, tak jak czynił to Durkheim, albo zaakceptować to, że maja one pewne transcendentne właściwości oddziałujące poza możliwościami ludzkiego działania, jak to czynili Simmel i Weber. Ale Twoje pytanie odnosi się do tej drugiej tradycji, do erupcji [irruption] łaski. Zagadnienie łaski stawia $\mathrm{w}$ socjologii dylematy podobne do tych, które osadzone są w Weberowskim użyciu pojęcia charyzmy, rozpiętego między nieoczekiwaną erupcją a przewidywalnościa. W jednym rozumieniu laska jest niespodzianką, darem z niebios, chwilową epifanią. Ale to drugie rozumienie odnosi się do kanalizowania tej łaski w sakramentach, gdzie jej udzielanie jest rutynowe, obiektywne i oczekiwane. Te sakramenty moga ilustrować to, co ma na myśli Balthasar, mówiąc o konkretnych, określonych właściwościach łaski.

Laska może mieć znaczenie fundamentalne, jak na przykład w formach uświęcania, szczególnie w chrzcie. Fragment o łasce w Katechiz̨mie jest myląco krótki, zajmuje bowiem jedynie trzy strony (KKK, kan. 4346). Ta zwięzłość może odpowiadać założeniu, że normatywnie łaska jest kanalizowana przez sakramenty, które pasują do wszelkich warunków życia. Te sakramenty są ustanawiane jako zewnętrzne znaki wewnętrznej łaski, udzielanej obiektywnie, choć wymagają czasem pewnych kwalifikacji u aktorów. $\mathrm{Na}$ przykład celowe pomijanie grzechu śmiertelnego sprawia, że sakrament spowiedzi jest nieważny. Łaska wymyka się rozumieniu, ponieważ sakramenty, takie jak Eucharystia, łączą to, co zwyczajne, z tym, co niezwykłe. W trakcie transsubstancjacji dochodzi do przeistoczenia tego, co powszednie, chleba i wina, w to, co niezwykłe, a co katolicy uznaja za Ciało i Krew Chrystusa. Pozwolenie na to, by Objawienie było podatne na przypadkowe okoliczności społeczne, byłoby szczytem arogancji. Pewne przyzwoite uporządkowanie, pewien rytuał są konieczne, by ustrukturyzować ów nakaz, by odtwarzać ten rytuał na pamiątkę, i ten nakaz sugeruje powtórzenia, które są zrutynizowane, a stąd bierze się potrzeba kanalizowania i władzy koniecznej, by to robić.

Zainteresowanie teologii laska jest powiązane także ze stanami życia, które sa podkreślane w Katechiæ̧mie. Rozszerza to pojęcie łaski ze sfer kościelnych także na obszar rutyny życia codziennego. Jednym ze szczególnych źródeł łaski, przesyconym implikacjami socjologicznymi, jest 
sakrament. Odnosi się on do zasobów łaski, które zależą od subiektywnych dyspozycji aktora. Odpowiada to artefaktom, symbolom i obrazom, które można by nazwać „konkretem”, a które przynoszą łaskę przez oddawanie czci i ich używanie. Sakramentalia to centralna własność kapitału duchowego, terminu, który odsyła nas do Bourdieu i jego pojęcia habitusu.

Będąc darem od Boga i potwierdzając życie zgodne z Duchem, łaska może wydawać się tematem czysto teologicznym, odpornym na interwencję socjologiczna. Ale to oznaczałoby, że należy zapomnieć o centralnym pojęciu łaski u Webera. Pierwsza sfera odnosi się do Etyki protestanckiej, której teza wiąże się z rozpoznaniem łaski jako środka do ukojenia obawy o własne zbawienie. Ta teza zwracałaby się ku wyrazom łaski jako erupcjom, a nie jako skanalizowanym środkom sakramentalnym. Laskę można odnaleźć w tym świecie i jest ona potwierdzana za pomocą regulacji cnoty. Drugi obszar odnosi się w sposób oczywisty do charyzmy jako formy władzy. Dar łaski został przez Webera zsekularyzowany i użyty jako środek do zrozumienia legitymizacji władzy politycznej (Carroll 2007). Istnieje jednak także istotna wariacja na temat jego pojmowania charyzmy, mająca głębokie implikacje teologiczne. Odnosi się ona do Weberowskiej koncepcji charyzmy urzędowej, której znaczenie stało się fundamentem do budowy teorii socjologii kultury Bourdieu. Oznacza zdepersonalizowana transmisję zdolności do konsekrowania i kanalizowania form łaski. To właśnie ta koncepcja stanowi kluczowy i niedoceniany zasób dla zrozumienia reprodukcji wierzeń religijnych. To jest właśnie socjologiczne antidotum na sekularyzację.

KT: Jeśli Bóg, Byt, Nieskonczony (niechaj przez chwile te stowa beda mogly być u̇̇ywane zamiennie) wkeracza w swiat przez kulture i w kulture, bez odpowiedzi jak dotad pozostaje pytanie o status produkcij kulturowej. Jeśli qaakceptujemy, że taska wkracza w kulture orazprzez kulture, to cay okereślone wytwory kultury sq bardziej odpowiednimi mediami dla jej nadejścia niž inne? A takize, rozwijajac te kwestie, cay zdolności podważania zastanego porzadku, jakimi charakteryzuje sie produkcja kulturowa, sa inspirowane cay praypadkowe? Kto lub co jest twórca kultury - Stwórca çy medium [originator or channeler]?

KF: Bliskie pokrewieństwo katolicyzmu z kultura zostało zaburzone w rezultacie oddziaływania naraz wielu czynników kulturowych i ekonomicznych, które sprawiły, że Kościół stracił swój monopol na mecenat i regulację tego, co nadaje się do pokazywania $\mathrm{w}$ przestrzeniach publicznych. Teraz wszyscy z bliska możemy oglądać [wytwory kultury - przyp. tłum.], zwłaszcza gdy użytkownik Internetu jest zarówno twórca, jak i medium obrazów, które oznaczają to, co jest wartościowe w kulturze. W niektórych 
częściach Europy i Ameryki Północnej sekularyzacja zmysłu wzroku jest tak zaawansowana, że dopiero niedawno niektórzy komentatorzy uświadomili sobie oddzielenie religii od sztuki współczesnej (Elkins i Morgan, 2009). W proteście przeciwko takiemu stanowi rzeczy moje dwie ostatnie książki były analizą restytucji obrazów ukradzionych religii w miejscach przeznaczonych do umoralniania. Wzrasta publiczne zrozumienie przeciwstawnych reakcji na obrazy w zależności od ich umiejscowienia - w katedrze czy też w galerii sztuki.

Niedawno kardynał Murphy-O’Connor zwrócił uwagę na tę kwestię, czym wywołał niemałą kontrowersję, gdy stwierdził, że majstersztyki sztuki sakralnej, zdeponowane obecnie w galeriach sztuki, powinny powrócić do kościołów. Miał na myśli Chrzest Chrystusa Piero della Francesca. Murphy-O’Connor podniósł fascynującą kwestię, mianowicie, że większość klasycznych dzieł renesansu znajdujących się w galeriach jest katolicka zarówno w warstwie ikonograficznej, jak i w przeznaczeniu (O'Connor 2008). Umieszczenie ich w galeriach sztuki wydaje się uzasadnione ze względu na zasady estetyki, których usprawiedliwienie nie wymaga odniesienia do oryginalnego kontekstu powstania. Galeria sztuki zawłaszcza sobie prawo do konsekrowania tego, co w tych obrazach jest wysublimowane i przez odniesienie do władzy jej wirtualnej religii udziela „łaski” tym, którzy przychodzą podziwiać jej święte obrazy. „Religia sztuki”, poprzez odwołanie się do wyższych form estetycznych duchowości i bezinteresowne uznanie, dąży do tego, by przedstawić Kościół jako zaściankowy, stronniczy i skapy w powierzaniu łaski tym, którzy przychodzą oglądać.

Jednakże te obrazy, nawet wyjęte z kontekstu i reprodukowane, w dalszym ciagu moga być medium łaski. Na przykład rozumienie rozmowy Archanioła Gabriela i Marii Dziewicy, czyli Zwiastowania (Łk 1, 26-35), jest niezmiernie wzmocnione dzięki świetlistemu sportretowaniu tej zbawczej sceny przez Fra Angelica. Mając wizualną reprezentację poślubienia Słowa, powiększa się poczucie piękna i wzniosłości tego momentu. Istnieje niebezpieczeństwo potraktowania łaski jako nagłej erupcji, która zakłada pasywnego odbiorcę, nieszczęsna, zaskoczoną ofiarę boskiego daru. Jednakże łaska i sakramentalia zakładaja sprawczość aktora, który otrzymuje dar. W ten sposób aktor może stać się kanałem łaski dla samego siebie, jak w wypadku szaty religijnej, gdy stara się być tym, na kogo wygląda.

Tak jak malarz ikon modli się do portretu, tak i socjolog oręduje o wydobycie teologicznych diamentów zagrzebanych w polu kultury. To, co przypadkowe [contingent], domaga się socjologicznego wyjaśnienia. Wydaje mi się, że w ten sposób przypadkowość i inspiracja w odniesieniu do kultury 
popularnej szłyby ręka w rękę, by przekształcić się w nadzieję na erupcje daru łaski.

KT: Czy kultura może mieć teologičnna dźwignie w warunkach, które Walter Benjamin zidentyfikowat jako masowa produkcje kultury? Zgodnie ze stowami Benjamina, gdy wytwory kultury moga być reprodukowane, traca aure swojej jedyności i swoja wartośc, ponieważ, „technika reprodukcji nyrywa reprodukowany obiekt ₹ ciagu tradycji”. Jake pisze, reprodukcja oznacza, że nytwór kultury jest dany publiczności, gdzie tylko owa publiczność sie znajduje, zamiast uymagać, by odbywano kolektywne lub rytualne pielgraymki do niego, i wszelka unikeatowość przestaje istnieć, ponieważ do dyspozycji mamy wiele reprodukcij. Tradycja zostaje ,unicestwiona” (Benjamin 1975: 70). Cજy masowe wytwory, pozbawione praywiazania do tej samej tradycji, która podważaja moga praynieść jakakolwiek erupcje?

KF: To pytanie dotyka pewnych bardzo skomplikowanych kwestii. Bez wattpienia unikatowość obiektów kulturowych jest podważana przez bezprzykładne zdolności wytwórcze masowej produkcji do powielania obrazów bez odniesienia do ich prototypów. Tyle treści jest prezentowanych w Internecie i dostępnych dzięki masowej turystyce, że troska Benjamina, iż „recepcja” następuje w stanie rozproszonej uwagi, zyskała szerokie potwierdzenie (Benjamin 1975: 91). Jednakże, jak odkryłem podczas pisania moich dwóch ostatnich książek, Benjamin ma rację jedynie połowicznie. Masowe produkty odzwierciedlają cuda technologii i w tym zakresie wszyscy moga zostać odwiedzeni od archaicznych konsekwencji rytuału. Lecz w tym geście odwiedzenia coś zostaje utracone i myślę, że „odzyskujący” to symbolizują, i stąd bierze się ich powrót do rytuału i pamięci o szerszej teologii, mającej moc przyzywania tajemnych sił. Katolicyzm jest genialny w sięganiu do zasobów swojej tradycji, do wydobywania wzorców, które moga zostać odnowione dzięki łasce nawet wtedy, kiedy otaczająca kultura traktuje je jako praktyki wymarłe. Co dziwne, rozwój kultury cyfrowej roztacza obrazy możliwości, w których działania niszowe znajdują własne miejsce, a porządki rytualne moga ulec przekształceniu stosownie do zupełnie nowych okoliczności.

Technologia ma niesłychaną zdolność do wzmożenia replikacji obrazów, ale Benjamin nie dostrzegł, że ta zdolność ma swój koszt. Wynikiem tej wizualnej obfitości jest ślepota, która bierze się z patrzenia nieselektywnego. Świadomość tego argumentu przejawia się w uzasadnianiu docenienia sztuki, gdzie kultywuje się potrzebę widzenia selektywnego. Po drugie, w całej kwestii obrazów i ich replik ignoruje się debaty na temat ikon, które już miały miejsce. Ikony są obrazem prototypu, który ujawnia się przez środki wizualne tym, którym dana jest łaska wychwycenia tego, co znajduje 
się poza wierzchnią warstwą ikony. Tak długo, jak wiara w ten prototyp jest potwierdzana i jak oko sięga do ukrytej głębi tego, co może być widziane, integralność ikony zostaje zachowana i wieczne używanie oraz kopiowanie ikony jest dozwolone. To, że aura ikony może być w tajemny i niewyczerpany sposób odnawiana, stanowi część jej tajemnicy. Ważne jest, aby odnotować, że znaczna część problemów związanych z estetyką u Benjamina odnosiła się do dzieł katolickich (Benjamin 1975: 75-76, 98-99).

Artefakty, obrazy, symbole oraz przestrzeń, w których są pokazywane, same w sobie nie moga zagwarantować efektów wizualnych. Moga jedynie zostać tak zaaranżowane, by zdawały się temu faktycznie sprzyjać. Świadomość, że kultura może zostać wykorzystana do wzmacniania władzy, legitymizacji iubóstwienia, nie jest niczym nowym. Rzymianie wykorzystywali to w architekturze, Henryk VIII stawiał pałace, które miały potwierdzić jego królewski status, a Ludwik XIV, Król Słońce, zbudował Wersal jako przedstawienie niezrównanego splendoru, który odpowiadał jego boskości. To, co święte, i to, co świeckie, było splątane, jako że w tamtych czasach religia była ważnym zasobem legitymizującym roszczenia władzy.

Co najbardziej intrygujące w kontekście współczesnej kultury masowej, to sposób, w jaki współczesne analizy historyków sztuki i kultura muzealna przypisuja sobie zdolności rearanżowania dawnych artefaktów religijnych w nowych narracjach, które oddają świeckie oczekiwania co do tego, co te dzieła powinny ukazywać pod względem estetyki. Te przekształcenia obejmuja przepakowanie tego, co przynależy do tradycji, lecz to przepakowanie służy dogodzeniu subtelnemu podniebieniu flaneura, zawsze gotowego chłonąć nowe ekscytujące wystawy.

KT: Jak dotad staratem sie zachecic Cie do myślenia o tradycji jako o wtasności kultury, ale te kwestie można takize rozważać na gruncie etycznym. Alasdair MacIntyre twierdzit, że wspótczesne spory o moralność moga zostać przezzyycieżone jedynie, jeśli nastapi przesuniecie od dominujacego stanu emotywizmu, w którym rozkaðy moralne sq redukowalne do twierdzeń o indywidualnych preferencjach, ku etyce cnoty, w której nakasy i dziatania sa zależne od kryterium doskonatości, zależnego od tradyciji (MacIntyre 1996). Podkreślateś takize istotność cnoty (Flanagan 2001b) w sposób, który wiaże ja ze zdolnościa do "widzrenia niewidocznego" (by zacytować jeden z. tytułón Twoich ksiażek, który sam odnosi sie do stów z Pisma Świetego). Cay postrzegasz. Kościót katolicki jako repozytorium etycznej doskonatości oraz, by odnieść moje pytanie z.powrotem do kultury, çy Kościót jest synym rozwiazaniem problemu ,unicestwiania tradycii", o którym mówit Benjamin?

KF: Moja praca doktorska (Flanagan 1978) oraz moje spotkania z Bourdieu $\mathrm{w}$ połowie lat siedemdziesiatych uformowały moje zainteresowanie 
potwierdzaniem charakteru. To zainteresowanie charakterem uległo intensyfikacji wraz z lektura pracy MacIntyre'a (1996), a po niej skierowało się w stronę etyki cnoty (Flanagan 2001b). Moje zainteresowanie charakterem oraz wizerunkiem zostało również ukształtowane pod wpływem Goffmana, który także miał wielki wpływ na Sogjologie $i$ liturgie oraz kolejne prace, a w szczególności ostatnią (Flanagan 2007).

W jakimś sensie wzrost cnoty religijnej wydaje się wykraczać poza możliwości ujęcia socjologicznego. Jest to historia, którą opowiada się rzadko i której odmawia się mobilizującego przekazu w mediach masowych. Zawsze chciałem przeprowadzić badanie relacji między ministrantem, chłopcem, a potem młodym mężczyzną, dorastającym jako sekretny praktykant u księdza, któremu służy. Ta sytuacja wydaje się wzorcowym przykładem metanoi [gr. nawrócenie] oraz mimesis, właściwości i procesów, które leżą w sercu problematyki reprodukcji wiary religijnej. Wzorem dla tego badania jest praca La Vocation: Conversion et reconversion des prêtres ruraux [Powołanie: konwersja i rekonwersja księży z parafii wiejskich] (Suaud: 1978). Ta praca dużo zawdzięczała Bourdieu i jego pojęciu habitusu. Chciałem przeprowadzić badanie wpajania kapitału duchowego wśród mniej znaczących aktorów liturgicznych, zarówno ministrantów, jak i członków chóru, u których kiełkuje zasiane ziarno powołania. Kryzys zakonów, załamanie się średnich seminariów duchownych, odkrycie wielu skandali pedofilskich oraz cała masa restrykcyjnych zakazów sprawily, że zebranie materiałów do takiego studium stało się właściwie niemożliwe. Ale prawdziwa trudność leży w zahamowaniach księży w odniesieniu do kształtowania duchowego młodych.

By podjąć takie badania, należałoby wprowadzić program obmyślony na podstawie oczekiwań socjologicznych, który byłby skupiony na wpajaniu duchowości u tych młodych rzemieślników liturgii oraz na ewaluacji tego skutków. W rezultacie socjologia zaczęłaby produkować teologiczne uprawomocnienia swoich wcześniejszych stwierdzeń.

KT: Ostatnie pytanie: Twoje prace sq otwarcie katolickie. Cay Twoim celem jest ewangelizacja? Albo zapytam inaczej - çy Twoja praca jest praca misjonarza w jadrze akademickiej ciemności?

KF: Pisanie uznaję za zajęcie bardzo prywatne i jestem poniekąd zakłopotany, gdy ludzie odpowiadaja na to, co piszę. Być może odzwierciedla to świadomość, że to, co piszę, jest specyficzne, moja proza jest gęsta i to, co się z niej wyłania, sytuuje się między socjologia i teologia. Pomimo tej interdyscyplinarności wiele z moich prac nie pasuje do współczesnej kulturowej wizji brytyjskiego uniwersytetu. 
Używanie socjologicznego języka do formułowania wypowiedzi teologicznych może wydawać się przykładem analitycznej próżności. Trudności z wysłowieniem się pogłębia świadomość, że wypowiedzi teologiczne często dotyczą tego, co niewypowiadalne. Dyscyplinarny patos, który rodzi się z tego nawarstwienia, zdaje się negować dar języków u socjologów. Nawet jeśli ich wołanie na puszczy to skuteczne prośby do Wszechmogącego, w przebraniu jakiej dyscypliny mają być dostrzegane? Czy ich autorzy maja jawić się jako socjologowie czy jako wybrakowani teolodzy? Czy w swoich zmaganiach z nowoczesnością socjologowie sa skazani na to, by przywdziać płaszcz mroku, który Weber określił jako odpowiedni ubiór dla tych, którzy widzą tę epokę lodowcową, czy też inne szaty, szaty nadziei, białe i jasne byłyby także dostępne? Wędruje się po tekstach pomiędzy krainą czarów a dziczą bez żadnej pewnej tożsamości przodków czy wzorów lub też zakorzenienia w polu kultury. Jednakże to zadanie w żadnej mierze nie jest beznadziejne; teologiczne zagadki, które komplikują socjologiczne deliberacje, maja swoją wartość. Znajomy socjolog, a zarazem szkocki ksiądz katolicki James Sweeney dobrze ujął nadzieje na kreatywne wyzwolenie. Pisząc do mnie z podziękowaniem za napisanie recenzji jego książki, zakończył swój list słowami: „będę odprawiał mszę w Twojej intencji z wielką chęcią oraz modlił się o to, by nasza socjologia pomagała wyostrzyć naszą wiarę oraz, co ważniejsze, by nasza wiara kształtowała naszą socjologię". Jak się wydaje, takie obustronne zaangażowanie to najlepsza droga naprzód.

\section{/// Wnioski}

Max Weber, odmawiając ignorowania tego, co teologiczne, rzucił klątwę w samym sercu powołania socjologii (Weber 1998). Nauka może wywieść techniczne i instrumentalne prawa, ale nie jest w stanie określić ich znaczenia. Na przykład nowoczesna medycyna istnieje po to, by podtrzymywać życie i zmniejszać cierpienie, lecz „czy życie jest warte tego, żeby je przeżyć, a jeśli tak, to w jakich wypadkach? - o to już medycyna nie pyta”. Weber kontynuuje: „,wszystkie nauki przyrodnicze dają nam odpowiedź na pytanie, co powinniśmy czynić, aby opanować życie w sposób techniczny. Nie daja jednak odpowiedzi na pytanie (...) czy naprawdę chcemy i czy powinniśmy opanowywać życie w ten sposób oraz czy ma to w ogóle jakiś sens?" (Weber 1998: 127). Nauki o kulturze, zgodnie z tym, co twierdzi Weber, umożliwiaja zrozumienie źródeł fenomenów artystycznych i społecznych, ale sa zupełnie niezdolne do udzielenia odpowiedzi na pytanie, czy warto je znać (Weber 1998: 128). Weber wiedział, że to przekleństwo 
wywołało u socjologów konieczność zdecydowania, gdzie leży ich powołanie, w których z ostatecznych wartości.

Prace Flanagana prześladuje klątwa Webera. Flanagan stawiał mniej więcej to samo zagadnienie przez pryzmat prac Kierkegaarda. Spekuluje on iż, jak „się wydaje, imperatywy skłaniające do skoku wiary pozostaja endemiczną cechą socjologii: jej stałą niezdolnością do pogodzenia się z tym, co Kierkegaard wyróżnił jako »zewnętrzność« obserwacji naukowej od »wewnętrzności« doświadczenia duchowego". Flanagan wyciaga wniosek, że z tej perspektywy można zrozumieć, że ,jednostka [self] wciąż pozostaje arbitrem swego ostatecznego przeznaczenia" (Flanagan 2008: 237, tłum. KM). Jednostka może wybrać kierunek skoku. W następstwie swojego nawrócenia Kieran Flanagan skacze, i to skacze zdecydowanie, w stronę katolicyzmu. Jego praca jest wytworem refleksyjnej jaźni, która wymaga obustronnego zaangażowania odrębnych uniwersów teologii i socjologii, by móc kroczyć dalej. Jego dzieło jest niemożliwe bez refleksyjnego nastawienia zarówno socjologii, jak $i$ teologii.

Recepcja prac Flanagana stawia pytanie o to, na ile faktycznie zachowujemy otwartość umysłu, głosząc przywiązanie do multidyscyplinarności. Reakcja na jego wysiłki zmierzające do przeniesienia socjologii w obręb teologii i stawiania pytań teologicznych z perspektywy socjologicznej, była w znacznej mierze chłodna po obu stronach. Wysiłek, który podejmuje, jest niewygodny dla obu dyscyplin. Mimo tego że socjologowie, z których dorobku czerpie najczęściej (Bauman, Bourdieu, Goffman, Simmel, Weber), cieszą się wysokim statusem w socjologii, używał ich prac do naświetlenia kwestii teologicznych. W efekcie interpretacje Flanagana moga jawić się jako dziwnie idiosynkratyczne, jego spojrzenie na innych socjologów niekoniecznie „przystaje” do mądrości dyscypliny, która mówi, jak „powinno się” ich czytać. Jego teologia wywołuje zdziwienie w ramach dyscypliny, która sama ma swoją niemalże-religię w postaci świeckości (Rieff 2007).

Lecz być może - być może - prace Flanagana są nie tyle dziwaczne, ile raczej nieco wyprzedzają swoje czasy. W socjologii zaczyna się mówić o postsekularyzmie i stawiać w centrum pytania o powtórne zaczarowanie i trwałość religii. Debata ta otworzy nas na pytania teologiczne lub przynajmniej - naświetli martwe punkty dyscypliny, które Flanagan starał się już zidentyfikować i wyjaśnić. Drugim powodem do poświęcenia uwagi jego wysiłkom na rzecz połączenia teologii i socjologii jest wzrost roli islamu w świecie zachodnim. Polityka i kultura islamu może być zrozumiana tylko przez odniesienie do jego teologii. Jeśli w tym punkcie dajemy za wygrana, 
to w którymś momencie socjologia będzie zobligowana do takiego samego ustępstwa wobec chrześcijaństwa. Trzeba będzie uwzględnić fakt, że chrześcijańska polityka i kultura maja sens jedynie wtedy, gdy są odnoszone do teologii chrześcijańskiej. Flanagan oczywiście może być krytykowany za przedwczesne oddawanie całego terytorium chrześcijaństwa katolicyzmowi, lecz być może tym samym postawił on znaki drogowe na terytorium, które pozostaje do przebycia. Niniejsza rozmowa to przewodnik po tych znakach drogowych, przewodnik po miejscach, z których można ruszyć w kolejne wędrówki. To antycypacja wyzwań, z którymi być może wszyscy będziemy musieli się uporać, i to raczej wcześniej niż później.

Bibliografia:

/// Balthasar H.U. von. 1982. The Glory of the Lord: A Theological Aesthetics, t. I. Seeing the Form, tłum. E. Leiva-Merikakis, T. \& T. Clark, Edinburgh.

/// Balthasar H.U. von. 1986. The Glory of the Lord: A Theological Aesthetics, t. III: Studies in Theological Style: Lay Styles, tłum. A. Louth, J. Saward, M. Simon, R. Williams, J. Riches (red.), T. \& T. Clark, Edinburgh.

/// Balthasar, H.U. von. 1988. Theo-Drama: Theological Dramatic Theory. I: Prologomena, tłum. G. Harrison, Ignatius Press, San Francisco.

/// Balthasar H.U. von. 1991. A Resumé of My Thought, [w:] Hans Urs von Balthasar: His Life and Work, D.L. Schindler, Ignatius Press, Fort Collins, s. $1-5$.

/// Balthasar, H.U. von. 1996. Bernanos: An Ecclesial Existence, thum. E. Leiva-Merikakis, Ignatius Press, San Francisco.

/// Benjamin W. 1975. Dzieło sztuki w dobie reprodukcji technicznej, [w:] Twórca jako wytwórca, red. Hubert Orłowski, Wydawnictwo Poznańskie, Poznań, s. 66-105.

// / Carroll A.J. 2007. ProtestantModernity: Weber, Secularisation andProtestantism, Scranton University Press, Scranton.

/// Katechizm. 1992. Katechiz̨m Kościoła katolickiego, http://www.tezeusz. $\mathrm{pl} / \mathrm{cms} / \mathrm{tz} /$ fileadmin/user_upload/startowa/KATECHIZM_KO_ CIO_A_KATOLICKIEGO.pdf; dostęp: 11.10.2013.

/// Mikołaj z Kuzy. 1997 Selected Spiritual Writings, tłum. H. Lawrence Bond, Paulist Press, New York.

/// Elkins J., Morgan D., red. 2009. Re-Enchantment, Routledge, New York. 
/// Flanagan K. 1978. The Rise and Fall of the Celtic Ineligible: Competitive Examinations for the Irish and Indian Civil Services in relation to the Educational and Occupational Structure of Ireland 1853-1921, rozprawa doktorska, University of Sussex.

/// Flanagan K. 1981a. Competitive Assemblies of God: Lies and Mistakes in Liturgy, „Research Bulletin of the Institute of Worship and Religious Architecture", University of Birmingham, Birmingham, s. 20-69.

/// Flanagan K. 1981b. The Experience of Innocence as a Social Construction, „Philosophical Studies” 1981, t. 28, s. 104-139.

/// Flanagan K. 1985. Liturgy, Ambiguity and Silence: The Ritual Management of Real Absence, "The British Journal of Sociology” 1985, t. 36, nr 2, s. 193-223.

/// Flanagan K. 1986. To be a Sociologist and a Catholic. A Reflection, „New Blackfriars" 1986, t. 67, wyd. 792, s. 256-270.

/// Flanagan K. 1991. Sociology and Liturgy: Re-presentations of the Holy, Macmillan, London.

/// Flanagan K. 1996. The Enchantment of Sociology: A Study in Theology and Culture, Macmillan, Basingstoke.

/// Flanagan K. 2001a. Reflexivity, Ethics, and the Teaching of the Sociology of Religion, „Sociology” 2001, t. 35, nr 1, s. 1-19.

/// Flanagan K. 2001b. Vice and Virtue or Vice Versa: A Sociology of Being Good, [w:] Virtue Ethics and Sociology: Issues of Modernity and Religion, red. K. Flanagan, P.C. Jupp, Palgrave Macmillan, Basingstoke, s. 104-124.

/// Flanagan K. 2004. Seen and Unseen: Visual Culture, Sociology and Theology, Palgrave Macmillan, Basingstoke.

/// Flanagan K. 2007. Sociology in Theology: Reflexivity and Belief, Palgrave Macmillan, Basingstoke.

/// Flanagan K. 2008. Sociology into Theology: The Unacceptable Leap, „Theory, Culture \& Society" 2008, nr 25, nos. 7-8, s. 236-261.

/// Flanagan K. 2009a. Conversion: heroes and their sociological redemption, [w:] Conversion in the Age of Pluralism, red. G. Giordano, Brill, Leiden, s. 33-71.

// / Flanagan K. 2009b. What's in a Name? The Fate of Sociology in Theology. The Michael Keenan Memorial Lecture 2007, St Thomas More College, Saskatoon.

/// Flory R., Miller D.E. 2008. Finding Faith: The Spiritual Quest of the PostBoomer Generation, Rutgers University Press, New Brunswick. 
/// Goffman E. 1977. Człowiek w teatrze sycia codziennego, thum. H. Datner-Śpiewak, P. Śpiewak, PIW, Warszawa.

/// MacIntyre A. 1996. Driedzictwo cnoty. Studium z teorii moralności, tłum. A. Chmielewski, PWN, Warszawa.

/// Milbank J. 1990. Theology and Social Theory. Beyond Secular Reason, Blackwell, Oxford.

/// Mills J.O. 1980. Introduction: Of Two Minds, [w:] Sociology and Theology: Alliance and Conflict, red. D. Martin, J.O. Mills, W.S.F. Pickering, The Harvester Press, Brighton, s. 1-14.

/// Murphy-O'Connor C. 2008. „The Times”, 27 listopada 2008.

/// Rieff P. 2007. Charisma: The gift of grace and how it has been taken away from us, Pantheon, New York.

/// Simmel G. 1997. Essays on Religion, red. i tłum. Horst Jürgen Helle, Yale University Press, New Haven.

/// Suaud C. 1978. La vocation: conversion et reconversion des prêtres ruraux, Les Éditions de Minuit, Paryż.

/// Weber M. 1948. Nauka jako zawód i powołanie, [w:] Polityka jako zawód i powołanie, tłum. P. Dybel, Społeczny Instytut Wydawniczy Znak, Fundacja im. Stefana Batorego, Kraków-Warszawa, s. 111-140.

Przekład Karolina Mikołajewska i Stanisław Burdziej

\section{/// Abstrakt}

Dla Kierana Flanagana, brytyjskiego socjologa eksplorującego pogranicze tej dziedziny z teologia, katolicyzm to „kreatywny stan liminalny”. W rozmowie z Keithem Testerem opowiada o tym, jak doświadczenie powrotu do religii wpłynęło na jego zainteresowania socjologiczne, owocując m.in. pracami na temat liturgii oraz wizualności. Odwołując się do „postsekularnych” wątków w pracach klasyków, takich jak Bauman, Bourdieu, Goffman, Simmel i Weber, Flanagan otwiera przed socjologia nowe problemy i perspektywy, wcześniej pomijane przez „religijnie niemuzykalnych" badaczy społecznych. Opowiada też o przygotowywanej obecnie pracy pod tytułem Sociology at Prayer. Zdaniem Testera ów pozornie 
dziwaczny mariaż socjologii i teologii może w istocie stanowić zapowiedź głębokich zmian, z jakimi socjologom wkrótce przyjdzie się uporać.

Słowa kluczowe:

Kieran Flanagan, Keith Tester, teologia, socjologia religii

\section{/// Abstract}

For Kieran Flanagan, British sociologist exploring the relationship between theology and sociology, Catholicism is a 'creative liminal state'. In a conversation with Keith Tester he talks about how his experience of coming back to religion influenced his sociological interests, materializing in works about liturgy and visual culture, among others. Referring to 'postsecular' motifs present in classics, such as Bauman, Bourdieu, Goffman, Simmel and Weber, Flanagan opens up new problems and perspectives, previously ignored by social scholars who lacked the 'religious ear'. He also tells us about a forthcoming book on Sociology at Prayer. According to Tester, this seemingly awkward marriage between sociology and theology may indeed foretell deeper change, which sociologists may soon have to face.

Keywords:

Kieran Flanagan, Keith Tester, theology, sociology of religion 